\title{
CULTURAL MANIFESTATION IN AN ELECTRONIC EFL TEXTBOOK FOR SENIOR HIGH SCHOOL
}

\author{
Imam Santosa* \\ STKIP Media Nusantara Citra \\ Received on 8 October 2019 / Approved on 14 October 2019
}

\begin{abstract}
This study aims to find out the manifestation of culture in English electronic textbook for Senior highschool by Puskurbuk. The study utilizes a content analysis as a research method to explore the cultural element in an Electronic English Textbook for Senior high school in Indonesia. The study probes around cultural element or cultural manifestation in the textbook, in which the main points-cultural features in cultural element comprises of eight different manifestations; cultural identity and social group, social interaction, belief and behaviour, social and political institutions, socialization and life cycle, national history, national geography and national identity The result of this study revealed cultural manifestations in the textbook consisting of $28 \%$ stereotype and national identity, which made up to almost one-third of the whole cultural occurrences. The remaining sequential amount of the cultural occurrences in the textbook are cultural identity and social group with $17 \%$. Social and political institution, along with national geography, gained $13 \%$ of cultural manifestations. Social interaction (9\%), belief and behaviour (7\%), socialization and life cycle (7\%) and the $6 \%$ occurrence of national history were the least elements found in the data observed. This study is beneficial to give the insight of cultural manifestation portrayal in the textbook.
\end{abstract}

Keywords: English Textbook, Culture, Cultural element

\section{ABSTRAK}

Penelitian ini bertujuan untuk mengetahui manifestasi budaya dalam buku teks elektronik bahasa Inggris untuk sekolah menengah atas oleh Puskurbuk. Penelitian ini menggunakan analisis isi sebagai metode penelitian untuk mengeksplorasi unsur budaya dalam Buku Teks Bahasa Inggris Elektronik untuk sekolah menengah atas di Indonesia. Studi ini menyelidiki sekitar elemen budaya atau manifestasi budaya dalam buku teks, di mana fitur utama poin-budaya dalam elemen budaya terdiri dari delapan manifestasi yang berbeda; identitas budaya dan kelompok sosial, interaksi sosial, kepercayaan dan perilaku, lembaga sosial dan politik, sosialisasi dan siklus hidup, sejarah nasional, geografi nasional dan identitas nasional. Hasil penelitian ini mengungkapkan manifestasi budaya dalam buku teks yang terdiri dari $28 \%$ stereotip dan identitas nasional, yang merupakan hampir sepertiga dari seluruh kejadian budaya. Jumlah sisa kejadian budaya dalam buku teks adalah identitas budaya dan kelompok sosial dengan 17\%. Lembaga sosial dan politik, bersama dengan geografi nasional, memperoleh 13\% . selanjutnya, manifestasi budaya. Kategori Interaksi sosial (9\%), kepercayaan dan perilaku (7\%), sosialisasi dan siklus hidup (7\%) dan 6\% kejadian sejarah nasional adalah unsur yang paling sedikit ditemukan dalam data yang diamati. Penelitian ini bermanfaat untuk memberikan wawasan penggambaran manifestasi budaya dalam buku teks.

Kata Kunci: buku bahasa Inggris, budaya, elemen budaya

\section{INTRODUCTION}

Language does not transpire segregated but it is the segment of a society and culture. It is believed that culture is embedded component on language. Soler \& Jorda (2007) examined that language can be properly understood with reference to the cultural context around it. This cultural integration into classroom context remains

\footnotetext{
*Author(s) Correspondence:

E-mail:imam_santosa@stkipmnc.ac.id
} 
integral especially in relation to, partly, satisfying the needs of the curriculum being devised, Wandel (2002) exposed the importance of target culture in teaching EFL in India to grasp the idea of communication. Hence, Kramsch (2011) showed that cultural understanding lead the communication between intercultural communicator avoid conflict and misunderstanding.

The study of the importance of culture in language teaching and learning has been conducted in many different points of view. Otwinowska \& Kasztelanic (2011) determined the importance of culture in the European Union. The policy being debated was the stress of the need of culture special treatment in the school system. The researcher posed the question about the portion of culture and the need of culture in language learning. Results of the study showed that the respondent that consisted of teachers and teenagers mostly believed that they need to obtain an understanding of target culture. The finding of the research also revealed that the respondents considered the importance of culture to preserve cultural identity. This is only to say that the students themselves possessed an intrinsic motivation of learning about culture, beyond the baselining curriculum, in the classroom context. Moreover, Thanasoulas (2001) examined the importance of culture as an integral part in foreign language teaching. The researcher believed that culture brings many benefits to the development of students in learning language. Those benefits would rise cultural awareness among students that lead them to anticipate the way of target culture use the language. The study also suggested the teacher should not be ignorant with stereotype that exist in the foreign language learning process, which in turn highlights the impetus for the English instructors to have a certain level awareness of target culture. In addition, Purba (2011, pp. 25-58) argued that culture is important in English foreign language teaching. The researcher examined some literature and article which concluded the importance of culture. The argument is based on the findings that culture and language is inseparable, student needs to anticipate acculturation and for successful skills obtainment, especially in regards to speaking skills of the target language. Another study that revealed the importance of culture in foreign language teaching was conducted by Bronwyn (2003). Brownwyn (2003) pointed out the importance of culture in term of appropriateness in communication. Teaching language alongside culture was believed help the learner to associated language use in culturally appropriate behaviour.

There are several aspects than influence teaching culture on language learning process. Tran (2010) pointed out three of those three main factors. Teacher, Curriculum and textbook are the most important factor that need to be considered. And textbook is the most essential factor among other. Cortezzi and Jin (1999) argued that textbook should contain cultural element. It is also believed that textbook serve various roles in culture learning process. Those are as a a teacher, a map, a resource, a trainer, an authority, a de-skiller, and an ideology. Adaskou, Britten and Fahsi (1990) supported the idea of textbook carries culture. It stated that cultural information could be carried on textbook material on several basis such as (1) Informative or descriptive text, (2) Text presenting foreign attitudes and opinions, (3) Human-interest texts (including dialogues), authentic or fictions with details of everyday life, (4) Questionnaires, contextualized practice activities, writing tasks, Lexis, idiom, and unfamiliar collocation, (5) The exponents of communicative function, (6) Illustration and (7) Sound recording.

In addition, Bryam (1993) contemplated the existence or the manifestation of culture inside the textbook. The elements are social identity and social group, social interaction, belief and behaviour, social and political institutions, socialization and life cycle, national history, national geography and national identity. the analysis of cultural element in the textbook deliver the insight on how intercultural communication reflected inside.

\footnotetext{
*Author(s) Correspondence:

E-mail: imam_santosa@stkipmnc.ac.id
} 


\section{LITERATURE REVIEW}

\section{Culture}

Culture is defined as the way of life, especially the general customs and belief, of a particular group of people at particular time (Cambridge Dictionary, 2016). But, in fact, culture has expanded its definition more than it is defined. William (Storey, 2012)) defined culture as one of the most complicated words in English language. This is not only because of its historical development, but essentially culture also has become one of important concept in several distinct discipline and in several distinct of perception. According to Kramsch,(2011) there are two different ways of understanding culture. The first one is derived from the study of the humanities. From this perspective culture is the way a social group represents itself and others trough material productions, such as art, literature, mechanisms of preservation and reproduction through history. The second way of understanding culture sees the phenomenon as derived from the contributions of social sciences and involves attitudes, beliefs, and way of thinking, behaving and remembering shared by members of a community. Both definition lead to two different approaches to the study of culture: the historical and ethnographic.

Culture through language brings or represent the identity of the speaker (Hall, 1997). Hall construed how culture construct the meaning trough language as a central construction. The representation of sign or symbol that exist in the world carries its own identity in each different culture. Each culture also has different perception and interpretation. But, the interpretation can be in similar ways. It makes culture sounds unitary and universal. The same interpretation of culture in the world called 'shared meaning' (Hall, 1997). Thus, each symbol and sign have one, single, fix and unchanging meaning which tangled on them. In part, people give sign and symbol meaning by the framework interpretation which brings them. Hence, Culture in the language curriculum has five different views; communicative view, classical curriculum view, cultural-free-language view, deconstructional view, and competence view (Holme, 2002). First, communicative view defined based on communicative function of the language. Language can be used in many different contexts, especially in culture. Second is classical curriculum view. It is the view where the language is focused on its function as an access route to communicate. The culture which the language is utilized can enhance the intellectual value of the language. The third is instrumental or cultural-freelanguage view. This view defined as the process of language that has hidden political and cultural agenda in the language, language become the delivering tool. Fourth is deconstructionist view. It embraces many different strands of thought. The fifth is competence view. This view contend that the knowledge of language's culture is thought essential to a full understanding of a language's nuance of meaning. Knowledge of the culture is important to understand the language's actual meaning. In summary, each different view of culture in language reaches the same board assertion that language is to some extent a cultural construction.

\section{Intercultural Competence on Language Teaching}

The phenomena of language and culture are intimately related. Both phenomena are unique to humans and have therefore been the subject of a great deal of anthropological, sociological, and linguistic. Language, of course, is determined by culture, though the extent to which this is true is now under debate. The converse is also true to some degree: culture is determined by language - or rather. According to Fromkin, Rodman, \& Hyams (2014, p. 429) language defined as concrete construction of the learner and arises in society life which involve different factors. Moreover, Sapir (1921) believed that Language is a purely human and noninstinctive method of communicating ideas, emotions and desires by means of voluntarily produced symbols. Edward Sapir with Benjamin Lee Whorf, recognized the close

\footnotetext{
*Author(s) Correspondence:

E-mail: imam_santosa@stkipmnc.ac.id
} 
relationship between language and culture, concluding that it was not possible to understand or appreciate one without knowledge of the other" (as cited in Wardhaugh, 2012, p. 222). Wardhaugh (Grabe \& Wardhaugh, 1988, pp. 222-223) maintained that (1) Language determines thought and culture; (2) Language influences thought and culture; (3) Culture influences people's language; and (4) Language and culture influence each other.

Krech explained (as cited in Xiao, 2010 , p. 9) the major functions of language from the following three aspects: (1) Language is the primary vehicle of communication; (2) Language reflects both the personality of the individual and the culture of his history. In turn, it helps shape both personality and culture; (3) Language makes possible the growth and transmission of culture, the continuity of societies, and the effective functioning and control of social group. In summary, there is relationship between culture and language. Culture can be reflected from the language. It also can be denied that the functions of language is as transmission of culture.

Foreign language learning is related to culture learning, and culture has been taught in the foreign language classroom implicitly. As Kramsch (1995, p.9) maintained culture in language learning is always in the background in classrooms when language learners are looking for a good communicative competence and challenging their ability to make sense of the world around them.

For English language teaching and learning, the concept of culture learning has developed over the decades. In addition, a review of development of culture learning in English teaching and learning was elaborated by Xiao (2001, pp. 31-53). First is grammartranslation. It was the main trend of language teaching in the 1950s. Foreign language teaching centered on knowledge of grammar, vocabulary, and reading in the target language in that period. Consequently, assessment took the form of translation exercises, vocabulary lists, dictations, and fill in the blank whose purpose was to measure linguistic gains. The emphasis was on cognitive understanding and rote reproduction of language rules rather than on communicative and sociolinguistic competence (Xiao, 2001, pp. 31-35). Culture in grammar translation method existed in order to appreciate ancient Greek products. It was resulting from the study of literature, geography, and other factual elements of the target culture of big "C" culture domain.

In the 1960s, culture learning was included in foreign language pedagogy. Kramsch (as cited in Xiao, 2001, p. 55) argued that the pedagogical innovation in that age led to an increased emphasis on developing the students' practical language skills, and could be used in teaching in language classroom. In this way, one could say that culture was taught in foreign language education in the form of the words and actions of everyday speakers in everyday life. In the 1970s-1980s, many foreign language theorists propose the inclusion of culture in a foreign language course because language learners should learn cultural content in order to use a foreign language, and cultural insights would enhance students' ability to communicate appropriately in situations of language use (as cited in Xiao, 2010, p. 12)

Celce-Murcia, Dornyei \& Thurel (1993) defined The term "Communicative Competence" as the knowledge of both rule of grammar and language use appropriate to a given context. Swain and Canale (1980) who attempted to define the specific components of the construct of communicative competence. The widely cited model by Canale and Swain (1980, pp. 1-47), later expanded by Canale (1983) subsumes four competencies under communicative competence: grammatical competence, sociolinguistic competence, strategic competence and discourse competence. Grammatical competence is concerned with mastery of the language code itself, including the mastery of phonological rules, morphological rules, syntactic rules, semantic rules and lexical items. Today it is usually called linguistic competence. Sociolinguistic competence addresses the extent to which utterances are produced and understood appropriately in different

\footnotetext{
*Author(s) Correspondence:

E-mail: imam_santosa@stkipmnc.ac.id
} 
sociolinguistic contexts depending on contextual factors. It focuses on the learning of pragmatic aspects of various speech acts, namely, the cultural values, norms, and other socio-cultural conventions in social contexts. Strategic competence is composed of two main strategies: (a) to compensate for breakdowns in communication due to limiting conditions in actual communication or to insufficient competence; and (b) to enhance the effectiveness of communication. And discourse competence concerns mastery of how to combine grammatical forms and meanings to achieve a unified spoken or written text in different genres (as cited in Marriane, Dornyei \& Thurel (1993).

The views bring us to the conclusion, as indicated in Lund's study, that foreign language learning is composed of several components, including grammatical competence, communicative competence, language proficiency, as well as attitudes towards cultural competence. Cultural competence, i.e., the knowledge of the conventions, customs, beliefs, and systems of meaning of another country, is indisputably an integral part of foreign language learning (Straub, 1999), and many teachers have seen it as their goal to incorporate the teaching of culture into the foreign language curriculum.

\section{Evaluating Textbook for Cultural Element}

Textbook, additionally, provide the basis for the content of the lesson, skill that thought, and variety of language practice (Richards, 2002). In addition, textbook has several benefits for teaching and learning activity, textbook provide a syllabus of the course, provide security of the students, provides visuals, reading and activities, provide assessment to the students, provide supporting materials, and provide consistency within a program (Graves \& Xu, 2000, p. 174). Brown (2003) states that textbook supports teacher in term of material and instruction. Textbook also give the teacher an idealistic thought of the lesson.

Cunningsworth (1995, p. 7) identify seven multiple roles of textbook in English language teaching. They are an effective resource for self-directed learning or selfaccess work, an effective resource for presentation material, a source of ideas and activities for learners' practice and communicative interaction, a reference source for students on grammar, vocabulary, pronunciation and other aspects of knowledge, a source of stimulation or idea in the classroom, a syllabus where they reflect predetermined learning objectives, and a support for less experienced teachers who have yet to gain in confidence.

Textbook reflects crucial position in teaching and learning activity on cultural basis. Cortezzi and Jin (1999) ascertained 7 functions of textbook. Textbook emerged as a teacher. It accommodates student that intended to instruct student directly about target culture. An overview of structured program of cultural element can be covered on the textbook. It also gives summary of the route of learning. Those considered as a map. Next, teacher highly relies material on the textbook. It emphasizes the role as a resource. A textbook is a trainer. It delivers novice teacher instructional guideline to lead teacher. A textbook is an authority. Its reliability and validity grants teacher unjustifiably content related culture. Textbook also delivers indisputable cultural view. However, the rich content and activity bestow limitation to over experience teacher. It is translated as de-skiller. The last role is ideology. Textbook pose the reflection of worldview and cultural system. The reflections discursively forge student's perspective on nation culture.

Cultural existence emerges in several forms inside the textbook. Adaskou, Britten, and Fahsi (1990, p.5) derived the forms of cultural features in language inside language teaching material. They are formative or descriptive text material; texts presenting foreign attitudes and opinions; human-interest texts (including dialogues), authentic or fictitious, with details of everyday life; questionnaires, contextualized practice activities, writing tasks; lexis, particularly idioms, and unfamiliar collocations, which involve alien concepts; the exponents of a communicative function; realia, or pseudo-

\footnotetext{
*Author(s) Correspondence:

E-mail: imam_santosa@stkipmnc.ac.id
} 
realia, of all sorts; illustrations other visuals; and sound recordings. Each of those carries cultural element inside textbook.

Cultural element takes a form inside textbook. Bryam (1993) comprehend shape of culture in the textbook. Byram splits cultural element into eight different form. The eight categories are: Cultural identity and social group encompasses national identity, including social class, regional identity, ethnic minority, and which manifest the intricacy of individuals' social identities and of a national society. Next is Social interaction conveys the behaviour in social interaction at differing levels of formality, as outsider and insider within social groups. Then, Belief and behaviour covers routine and taken-for granted actions within a social group and moral and religious beliefs. Social and political institution consist of state institutions, health care, law \& order, social security, and local government. Socialization and life cycle incorporate family, school, employment, media, and ceremonies which mark passage through stages of social life. National history which includes historical and contemporary events seen as markers of national identity. National geography which includes geographic factors seen as being significant by members. Stereotypes and national identity which includes what is typical or a symbol of a national identity or stereotypes, e.g., famous people or monuments.

\section{RESEARCH METHOD}

The purpose of this study to oversee the occurrence of cultural element in electronic EFL textbook for senior high school. Content analysis was utilized to explore cultural element in the electronic EFL textbook for senior high school. Content analysis as a research method is a systematic and objective means of describing and quantifying phenomena (Krippendorff 1980, DowneWamboldt 1992, Sandelowski 1995). It is also reconized as a method of analysing documents. Content analysis allows the researcher to assess theoretical issues to embellish understanding of the data. Through content analysis, it is possible to clarify words into fewer content related categories. It is inferred that when classified into the same categories, words, phrases and the like share the same meaning (Cavanagh 1997). Content analysis is a research method for making replicable and valid inferences from data to their context, with the purpose of providing knowledge, new insights, a representation of facts and a practical guide to action (Krippendorff 1980). The aim is to attain a condensed and broad description of the phenomenon, and the outcome of the analysis is concepts or categories describing the phenomenon. An English electronic textbook, entitled "Bahasa Inggris Kelas 10", was analysed. The book was published by PUSKURBUK in 2017 to accommodate teacher. Each form of cultural component in the textbook, as proposed by Cortezzi and Jin (1999) was analysed. To analyse the data, the component of textbook that contain culture devided into parts as proposed by Adaskou, Britten and Fahsi (1990) (1) Informative or descriptive text, (2) Text presenting foreign attitudes and opinions, (3) Human-interest texts (including dialogues), authentic or fictions with details of everyday life, (4) Questionnaires, contextualized practice activities, writing tasks, Lexis, idiom, and unfamiliar collocation, (5) The exponents of communicative function, (6) Illustration and (7) Sound recording. After that, those cultural components was classified into 8 cultural elements as proposed by Bryam (1993) that embedded inside cultural component. 8 classification are Social identity and social group, Social interaction, Belief and behaviour, Social and political institution, Socialization and life cycle, National history, National geography, and Stereotypes and national identity.

\section{FINDINGS AND DISCUSSIONS}

Based on the analysis of the book, the result of the analysis is presented below. The

\footnotetext{
*Author(s) Correspondence:

E-mail: imam_santosa@stkipmnc.ac.id
} 
chart depicts the cultural occurrence in English book "Bahasa Inggris, Grade X" by Puskurbuk. The overall result showed that stereotypes and national identity was the major cultural manifestation in the text book. The portion was $28 \%$ of total occurrence. It was almost $1 / 3$ of total occurrence.

\section{Cultural Manifestation}

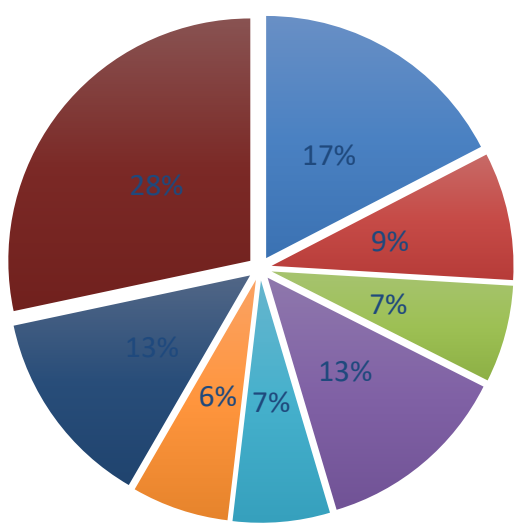
Cultural identity and social group $\square$ Social interaction
Belief and behaviour
- Social and political institution
- Socialization and life cycle
National history
national geography
- Stereotypes and national identity
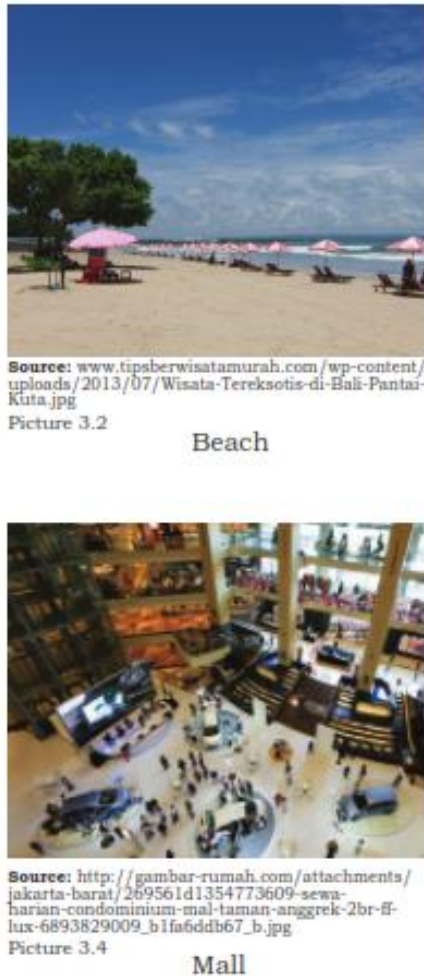

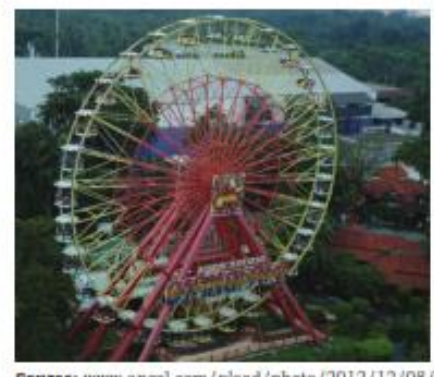

Source: www.ancol.com/ pload/photo/2012/12/08/

Amusement park

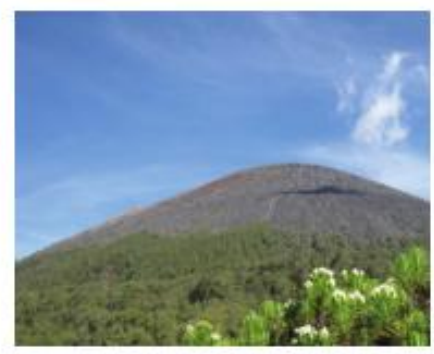

Source: http:/ / wildan220688. sles. wordprens.
com $/ 2012 / 10 / 01$-gunung-semers.jpg Com/2012/10/01-gunung-semeru.jpg Mountain

*Author(s) Correspondence:

E-mail:imam_santosa@stkipmnc.ac.id 
As presented above, the figure contains the cultural manifestation in Stereotypes and national identity category. The Ferris wheel of Ancol, Semeru and Bali became the identity of one particular nation. The landmark of the nation dominated the occurrences of this category. Besides, the quote of famous person was also be a factor of Stereotypes and national identity in the textbook. This finding is inline as Bryam (1993) theory.

Second highest appearance is Social identity and social group with $17 \%$. The fashion used by the example of the picture carried cultural manifestation in social identity and social groups. Besides, the human race in the world also demonstrate this category. The finding was relevant with the study by Byram (1993).

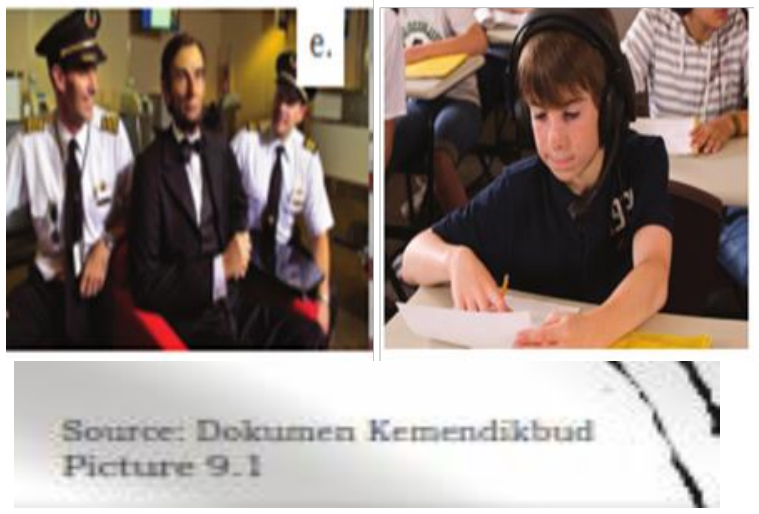

Next was social and political institution and national geography. Both cultural manifestations gain $13 \%$. The first category dominated by the source of material in the textbook; Kemendikbud (The Ministry of Education). The electronic textbook actually published by PUSKURBUK the institution under KEMENDIKBUD. Next, the figure below represented that. In other hand, national geography appeared similar like the previous category; stereotypes and national identity. The picture which represent the nation and the appearance of the name of place in the text

*Author(s) Correspondence:

E-mail: imam_santosa@stkipmnc.ac.id determine this category. It reflected on the figure below.

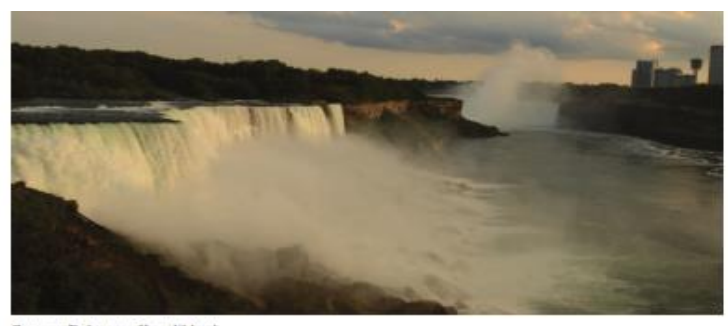
Source: Dokurn
Picture 5.3

Niagara Falls is the collective name for three waterfalls that cross the international border between the Canadian province of Ontario and the USA's state of New York. They form the southern

Niagara fall carried the cultural manifestation in the national geography category. Thus, it was pertinent with Bryam (1993).

Then, social interaction turned up $9 \%$ in the textbook. The appearance emerged in the dialogue. Next, belief and behaviour category calculation was $7 \%$. The temple, mosque, the veil, represented this category. It was showed in the figure below.

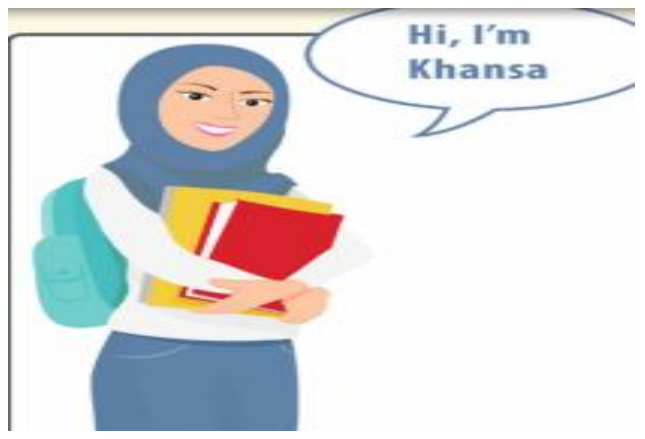

Socialization and life cycle category occurred $7 \%$ in the textbook. The picture of school life, family determined the occurrence of category.

Finally, the last one was national history with $6 \%$ appearance. This portion of cultural manifestation was the lowest. The representation of history in the textbook quite low. Entirely the appearance of this category 
mostly contributed in the chapter in the chapter 10 and 11 . In the chapter 10 the focus was B.J Habibie and the $11^{\text {th }}$ chapter was focused on the Cut Nyak Dien.

\section{CONCLUSION}

Based on the findings and discussion above, it can be concluded that the stereotype and national identity outnumber other manifestation. In the total of 299 of cultural manifestation in the textbook, $28 \%$ is stereotype and national identity. And the rest sequential amount of the cultural occurrence in the textbook are cultural identity and social group with $17 \%$. Next is social and political institution and national geography. Both cultural manifestations gain $13 \%$. And the rest is social interaction (9\%), belief and behaviour $(7 \%)$, socialization and life cycle $(7 \%)$ and the last one is national history with $6 \%$ appearance.

The occurrence of stereotypes and national identity were mainly associated with the famous person and the landscape of each nation. The quote of famous person exists in the last page of the chapter. Moreover, the chapter 13,14 were mainly discussed on the famous person history and deeds.

The next highest percentage is social identity and social group. The portrait of its manifestation occurred on the identity of each nation such as cloth and building. The social status that depicted in the textbook also consider as its manifestation of culture. moreover, the Indonesian culture seemed dominant that other culture on this occurrence. It was in line with the curriculum 2013 that command the insertion of national characteristic in the teaching and learning situation. Next highest percentage is social and political institution and national geography. It is kind of intriguing that the political and social institution of Indonesia emerge frequently in each chapter. The appearance of its manifestation mostly dominated by Kemendikbud (the education minister institution). It appeared as the source of material in the textbook. In the other hand, national geography arose in the cause of the example in the text and exercise of the book. The next occurrence was social interaction $(9 \%)$. It is presented in the dialogue in the textbook. Belief and behaviour mostly arise in the form of picture that represent religious cloth and building. Those result was relevant with Bryam (1993).

\section{REFERENCES}

Adaskou, K., Britten, D., \& Fahsi, B. (1990). Design decisions on the cultural content of a secondary English course for Morocco. ELT Journal, 44(1), 310.

Byram, M. (1993). Language and Culture: The Need for Integration. In M. Byram (Ed.), Germany, it's Representation in textbooks for teaching German in Great Britain (pp. 3-16). Frankfurt Am Main: Diesterweg.

Peterson, E., \& Coltrane, B. (2003). Culture in second language teaching. In Culture in Second Language Teaching. Center for Applied Linguistics. Retrieved from

ww.cal.org/resources/Digest/0309peter son.html

Brown, H. D. (2003). Language assessment principles and classroom practice. New York: Longman.

Byram, M., \& Grundy, P. (2002). Introduction: Context and culture in language teaching and learning. Language, Culture and Curriculum (pp. 193195).

Cambridge Dictionary. (2016). Retrieved from https://dictionary.cambridge.org.

Canale, M., \& Swain, M. (1980). Theoretical bases of com-municative approaches to second language teaching and testing. Applied linguistics, 1(1), 1-47.

Cavanagh S. (1997) Content analysis: concepts, methods and applications. Nurse Researcher, 4, 5-16.

*Author(s) Correspondence:

E-mail: imam_santosa@stkipmnc.ac.id 
Celce-Murcia, M., Dörnyei, Z., \& Thurrell, S. (1993). A pedagogical framework for communicative competence: content specifications and guidelines for communicative language teaching. In Deseret Language and Linguistic Society Symposium (Vol. 19, No. 1, p. $3)$.

Cortezzi, M., \& Jin, L. (1999). Cultural mirrors: Materials and methods in the EFL clasroom. Culture in Second Language Teaching and Learning. CUP: Cambridge, 196-219.

Cunningworth, A. (1995). Choosing your coursebook. Oxford: Macmillan Education.

Downe-Wamboldt, B. (1992) Content analysis: method, applications and issues. Health Care for Women International, 13, 313-321.

Fromkin, V., Rodman, R., \& Hyams, N. (2014). An introduction to language (10th ed). California: Wadsworth, Cengage Learning.

Grabe, W., \& Wardhaugh, R. (1988). An Introduction to Sociolinguistics. Language. https://doi.org/10.2307/415470

Graves, K., \& Xu, S. (2000). Designing language courses: A guide for teachers. Boston, MA: Heinle \& Heinle.

Hall, S. (1997). The work of representation. Representation: Cultural Representations and Signifying Practices. https://doi.org/10.1177/089801011039 3351

Holme, R. (2002). Carrying a baby in the back: Teaching with an awareness of the cultural construction of language. Language, Culture and Curriculum. https://doi.org/10.1080/079083102086 66645

Krippendorff, K. (1980). Content Analysis: An Introduction to its Methodology. Newbury Park: Sage Publications.

Kramsch, C. (2011). Language and culture. In The Routledge Handbook of Applied Linguistics. https://doi.org/10.4324/978020383565 $\underline{4}$

Otwinowska-Kasztelanic, A. (2011). Do We Need to Teach Culture and How Much Culture Do We Need? In Aspects of Culture in Second Language Acquisition and Foreign Language Learning. https://doi.org/10.1007/9783-642-20201-8 4

Purba, H. (2011). The Importance of Including Culture in EFL Teaching. Journal of English Teaching, 45-58.

Richards, J. C. (2001). The role of textbooks in a language program. RELC Guidelines, 23(2), 12-16.

Sandelowski M. (1995) Qualitative analysis: what it is and how to begin? Research in Nursing \& Health, 18, 371-375.

Soler, E. A., \& Jordá, M. P. S. (2007). Intercultural language use and language learning. In Intercultural Language Use and Language Learning. https://doi.org/10.1007/978$1-4020-5639-0$

Storey, J. (2012). Cultural Theory and Popular Culture. In Cultural Theory and Popular Culture. https://doi.org/10.4324/978131583296 8

Thanasoulas, D. (2001). The importance of teaching culture in the foreign language classroom. Radical pedagogy, 3(3), 1-25.

Tran, T. H. (2010). Teaching Culture in the EFL/ESL Classroom. Online Submission.

Wandel, R. (2002). Teaching India in the EFLClassroom: A Cultural or an Intercultural Approach? Context and Culture in Language Teaching and Learning, 72-80. doi: 10.21832/9781853596728-008

Wardhaugh, R. (2012). An Introduction to Sociolinguistic. Sidney: Blackwell.

Xiao, L. F. (2001). Teaching English Cultural Background: Introducing the Target Culture into Chinese Secondary School. Tampere University Press.

\footnotetext{
*Author(s) Correspondence:

E-mail: imam_santosa@stkipmnc.ac.id
} 
Xiao, J. (2010). Cultural Contents of an in-use EFL Textbook and English Major Students' Attitudes and Perceptions towards Culture Learning at Jiangxi University of Science and Technology, China. China: Prince of Songkla University.

*Author(s) Correspondence:

E-mail: imam_santosa@stkipmnc.ac.id 